\title{
Using Data Envelopment Analysis to Measure the Technical Efficiency of Public Hospitals in Turkey
}

\author{
Veri Zarflama Analizi ile Türkiye'deki Kamu Hastanelerinin Teknik Etkinliğinin \\ Ölçülmesi
}

Mehmet KARAHAN ${ }^{1}$

https://orcid.org/0000-0002-0402-0020

\begin{abstract}
In the study, it was targeted to increase the efficiency of business by identifying the performance and efficiency levels of 1533 public hospitals in 81 provinces of Turkey by means of data envelopment analysis and, in addition to this, identifying the problems of units causing disruptions; it was aimed to sort out these problems by suggesting solutions. The data obtained from health businesses, in which application was performed, were checked; their efficiency degrees were assessed; and analysis results were obtained. These results obtained from the study were used in the improvement studies that are going to be carried out to increase the efficiency of or remove the deficiencies of hospitals, in which application is performed. According to the results obtained, the technical efficiencies of 1533 businesses being active in 81 provinces and presenting similar health services were measured by means of data envelopment analysis and it was identified that 775 of these hospitals that are present in 36 provinces worked efficiently, and that 758 of them that are present in 45 provinces did not work efficiently.
\end{abstract}

Keywords: Data envelopment, efficiency analysis, hospital efficiency, health businesses

JEL Classification: H21, I11, P47, P27

\section{INTRODUCTION}

While health, as a service area, on the one hand, is directly interested in the human and social life, on the other hand, making contributions to the quality of factor labor, it also affect economic performance as a whole via the employment and production. It is very important to know the effectiveness levels of hospitals, which are businesses of health sector, beca-

\begin{abstract}
ÖZET
Çalışmada, veri zarflama analizi ile Türkiye'nin 81 ilindeki 1533 kamu hastanesinin performans ve etkinlik düzeyleri belirlenerek işletmenin etkinliğini artırmak hedeflenmiş, ayrıca hastanelerde aksamalara neden olan birimlerin sorunları belirlenerek çözüm önerileriyle bu sorunları düzeltmek amaçlanmaktadır. Uygulama yapılan sağlık işletmelerinden elde edilen veriler kontrolden geçirilecek etkinlik dereceleri değerlendirilmiş ve analiz sonuçları elde edilmiştir. Çalışmadan elde edilen bu sonuçlar, uygulamanın yapıldığı hastanelerin etkinliği artırmak veya eksikliklerinin giderilmesi için yapılacak iyileştirme çalışmalarında kullanılmışır. Elde edilen sonuçlara göre, 81 ilde faaliyet gösteren ve benzer sağlık hizmetleri sunan 1533 hastanenin teknik etkinliği veri zarflama analizi ile ölçülmüş ve bu hastanelerden 36 ilde bulunan 775 tanesinin etkin olarak çalıştığı, 45 ilde bulunan 758 hastanenin de etkin olarak çalışmadığı belirlenmiştir.
\end{abstract}

Anahtar Kelimeler: Veri zarflaması, etki analizi, hastane etkinliği, sağlık işletmeleri 
Assessing the performances of businesses in a certain slice of time is closely related to how rationally they behave, while transforming the inputs they use into the outputs. In this context, while the performance of an economic unit is evaluated, it is necessary to identify whether or not the maximum output is obtained from the inputs used or the output level determined is reached with the amount of minimum input. This assessment is carried out by Data Envelopment Analysis (DEA), developed to measure the relative performance of the businesses and one of the most used methods in the literature.

DEA is a non-parametrical method of measuring efficiency, which can be easily for more than one input and output. In addition, DEA can perform measurement, using the inputs and outputs such as cost, weight, and volume, which are very different from each other; and, in the units making decision such as hospital, using the input and output variables such as the number of bed, number of specialists and practicing physician, mortality rate, and currency capital, which are in the very different number from each other, an effective measurement of efficiency can be performed.

In this study carried out, the efficiency comparisons of public hospitals selected as an example were made by using DEA method. In the study, in the light of factors such as the structure and organization of health sector, financing health services, and health expenditures, relative efficiency analysis of public hospitals was made and, utilizing the findings obtained, the suggestions related to the health policies to be implemented were developed. In this study, in which the relative service performances of the hospitals are examined, data were obtained from the statistics, published in the official web site of Ministry of Health. Performance measurement based on the resource use efficiency of hospitals was performed according to the approach of DEA. While performance measurement are performed, including in the possibilities presented by DEA, the distinct models were used and hospitals were compared to each other according to the cases of constant return to scale and variable return to scale. In assessment of efficiency performance, the variables such as the number of total bed, specialist physicians, and nurses were used as input and the variables such as the number of patients treated, inpatients, surgical operations, and bed turnover as output. With this analysis, performing the measurements of resource use efficiency and performance at hospital level, it was aimed to reveal the efficiencies of hospitals to present health service.

\section{Data Envelopment Analysis}

While the first applications of DEA were generally carried out in non-profit organization, they, becoming wide later, have been begun to be applied in profit-oriented organizations as well. Among application areas, the hospitals, educational institutes, military units, local governments, airports, banks, hotels, and municipalities can be counted (Bowlin, 1998). DEA, first introduced by Charnes, Cooper and Rhodes (CCR) in 1978, is a linear programming process, in which a number of input and output are defined as boundary analysis (Charnes et al., 1978; Widiarto et al., 2017). The first DEA model, introduced by CCR, was built on the study by Farrel in 1957 (Cooper et al., 2004). The method largely attracted attention in the following years, and a number of theoretical and applied studies were carried out (Tavares, 2002). DEA is $s$ method, which produces multiple output in a production system, using multiple input, and which are used in measuring the relative efficiencies of decision making units (DMU), which carry out the similar duties (Yun et al., 2004).

DEA is a method, in which some mathematical programming methods are used, to compare the efficiencies of a group. That it requires that there are not any functional connections between inputs and outputs is the most important advantage of the method. This state brings the feature to be non-geometrical method in DEA (Ayricay and Ozcalici, 2014). DEA is a specific application form of linear programming (Tunca et al., 2010), commonly used in relatively measuring the effectiveness of the businesses, which are active in service sector and have the same aims and targets (Tetik, 2003).

DEA method is generally used for measuring the efficiency of a number of units such as production units, banks or hospitals, which are generally characterized with the complex inputs and outputs. In the process to obtain the desired outputs, efficiency and effectiveness analyses are very important managerial instruments in determining until what level inputs are used. In DEA, the units assessed are called decision making units (DMUs), and performance measurement is made by utilizing the input and output data (Yu, and Zhang, 2017). Particularly in the cases, in which the relationships between inputs and output are not known, it is a useful analysis method. The first model, 
developed by Charnes, Cooper and Rhodes, under the assumption of Constant to Return Scale (CCR), was later arranged by Banker, Charnes, Cooper under the assumption of Variable Return to Scale and brought a new dimension in efficiency measurement. This form of DEA is known as BCC model (Karahan and Akdag, 2014).

Since DEA is basically used for production efficiencies in the similar sort, the conditions that the decision units that can be the subject of analysis perform similar functions toward the same target, are active in the same market conditions, and all units in the group are the same except for the intensities and size of the factors qualifying their effectiveness are required. In addition, DEA is a method that can measure efficiency by using more than one input and output and is not affected from the distinctness of input and output units (Bayraktutan and Pehlivanoglu, 2012). In DEA service process, it can be generally obtained a number of outputs by using a number of outputs. That DEA has a feature to be a method considering all inputs and outputs in selecting a successful service unit of DEA is its aspect that is more advantageous compared to the other effectiveness analysis (Aslan and Mete, 2007).

DEA is a mathematical programmed-based technique used in measuring the relative efficiencies of organizational units having multiple inputs. Especially, in the cases, in which more than one input and output is not transformed into a weighted set of input or output, this technique is accepted as an efficient approach. The method accepts the best observation as efficiency boundary and following this, the other observations are evaluated to this observation that is most efficient. Later, when duality of each model is formed and solved, it is calculated that non-efficient units are not efficient according to which units and what the amounts of increase and decrease that is necessary to be done for providing efficiency are. What makes the method from others is that it accounts for optimal performance instead of average performances (Guzel et al., 2012).

While a production model is formed for health sector, it is necessary to process input and output more than one. Therefore, it is not suitable to predict the effectiveness of hospitals with less number of simple input and output coefficients. In calculations of hospital efficiency, for being able to get the desired results with minimum input, it is necessary to well predict the variables and, thus, it is possible to reach the maximum output level (maximum performance) with minimum input (Helmig and Lapsley, 2001). DEA method, thanks to these superior features of it, was used in analyzing the effectiveness of health organizations in the developed countries (Kirigia et al., 2004), measuring production effectiveness in Scotland (Parkin and Hollingsworth, 1997), increasing output quality of the hospitals in England (Thanassoulis, 1995), and many applications similar to these, and positive results were obtained.

\section{Application of Increasing Service Efficiency of Public Hospitals in Turkey}

Today, in parallel with the material and economic possibilities of the people, importance given to the presentation of health services has increased, and the sectorial data of service reached important dimensions. When the attempts of EU countries to converge health issues and excessive increases in health expenditures are considered, the issues such as effectively giving health services, increasing their service efficiency by continually controlling, and limiting the excessive expenditures have become an important focus for today's service presenters. In this context, through worldwide studies related to the subject, a wide literature review has been made, and some of the studies carried out on hospital-performance were summarized as follows.

Helmig and Lapsley (2001), in the study they carried out in Germany, in order to reduce the excessive cost increase, carried out a study by means of DEA method, and they tried to solve the problem with excessive cost, increasing the efficiency of the hospitals. In the study, as input variables, the number of bed, the number of health personnel (the numbers of physician, nurse and physicist, medical and technical auxiliary staff) and operational expenditures made and amount of all other expenditures were used. As output variable, the number of the inpatient and discharged patient and the amounts of expenditures made for the health and educational facilities were used. As a result of the study carried out, in all health facilities, between the years of 1991-1996, effectiveness increases at absolute level were provided and, in addition, as a result of the comparisons made between private and public sectors, it was concluded that the effectiveness of public hospitals is relatively higher and that public hospitals used relatively less resource.

Hofmarcher, Paterson and Riedel (2002), in the study, in which they examined the effectiveness and productivity development in health sector in Austria 
between the years of 1994-1996, utilized DEA method, using panel data, for being able to compare the effectiveness score between hospitals. As a result of the study, while output effectiveness of the first of two efficiency models, designed by the researchers, was average $96 \%$, the average of the second was calculated as $70 \%$. Average effectiveness in the first model moderately increased in the period of 1994-1996, it was observed that average effectiveness in the second model did not vary too much.

Ferrier and Valdmanis (2004), in the study titled "Can customers develop hospital effectiveness", comparatively examined two hospitals they selected and researched whether or not their effectiveness to be augmentable. The study covers the years of 19961998, and analyzes were made by means of DEA method. As a result of the study, it was put forward that thanks to short termed studies to be carried out, the performance of the hospital could be increased.

Hu and Huang (2004), in their studies, in which they studied the ways of reducing the health costs in Taiwan, among 637 hospitals in the country, 80 hospitals having bed more than 250 were studied as a sample, and effectiveness calculations of these hospitals were made by means of DEA. In the study, using official datasets belonging to the year 2001, technical efficiency scores of the hospitals were calculated. According to the results obtained from the study, it was put forward that the current effectiveness of the public hospitals selected as an example was significantly poor, and that it was necessary to increase the rates of capacity use. Again, according to the results obtained, it was suggested that the number of physician per capita, the number of bed, the number of room, the numbers of hospital, medical resource allocation, and external competitive factors significantly affected the effectiveness of the hospitals; that increasing bed turnover significantly increased the efficiency of hospitals; that the effectiveness of public hospitals in Taiwan was lower compared to private sector; and for this reason, privatizing public hospitals would be a suitable strategy.

Karagoz and Balci, (2007), in the study, in which they examined the effectiveness of departments giving education of health management in Turkey, administered a survey in 207 students of health management and made statistical analysis on the data obtained from the application. According to the results obtained from the study, it was identified that the efficiency levels of the departments was at moderate level and that the highest efficiency was in the dimension organizational health.

Garcia-Lacalle and Martin (2010), in the study they carried out, studied whether or not the reforms regarding health services in Europe affected the hospitals in the urban and rural regions and, in this context, the performance, effectiveness, and perceived qualities of the hospitals were compared to each other. The study focused on the policy of freedom to select hospital in Spain, and on the applications of repayment system of Andalusian Health Services (ASS), based on hospital performance, and covers a two years' period between the years of 2003 and 2006. As a conclusion of the study, it was identified that the rural and urban hospitals were similar to each other in the dimension effectiveness and that the hospitals in rural regions exhibited much better performance in the dimension patient satisfaction than those in urban regions and, therefore, it was put forward that market-based reforms made did not form a more difference in the performances of the rural and urban hospitals.

Dimas et al., (2012), in the study they carried out, assessed the variations in the effectiveness and technological development of 22 public hospitals in Greece. In the study, DEA method was used to measure the effectiveness of the hospitals, and it was tested whether or not environmental factors affected the effectiveness of the hospital. As a result of the study, it was identified that performance of public hospitals decreased by average $55.4 \%$ throughout duration of the study and that the major reason for this was high expenses related to the technical changes (operational expenses, purchase of medical equipment and material). In the study, it was argued that the improvement at efficiency level of the hospitals could be provided via better management and reallocation of the resources, and that this improvement would bring an extra profit of EURO 25 million in the hospitals for the duration of 3 years.

Davis et al., (2013), in a case study they carried out related to the performances of public hospitals in New Zeeland between the years of 2001-2009, made a comparison of 35 hospitals across the country in the dimensions of effectiveness, efficiency, and equality. In performance assessments carried out, the data such as hospital stay of the patients and the number of surgical operation daily performed were utilized and it was concluded that according to these data, performance differences between the hospitals was in the tendency to decrease in time. As a result of the study, for being 
able to assess the performances of public hospitals in New Zeeland at international level, it was expressed that it was necessary to develop a certain standard frameworks and criteria, and that many studies had to be carried out for this.

Oderkirk et al. (2013) carried out a study determining the standard data that can be used in improving the performance of health institutes and targeting them to be transformed into standard data that can be used at international level. In this scope, a survey application was made in 20 OECD countries and it was studied how health data published in these countries can be generalized and whether or not these data can form a problem for some countries. According to the results of the study, for strengthening national information structure, there is a need for the laws and policies providing data connection and data share and, for raising the quality of health services and performance of health system, it is necessary to standardize, store, and protect the data. Thanks to these data standardized, the common studies between OECD countries can be developed much more and performance assessments and comparisons of health system can be made more healthily.

Gholami et al., (2015), in the study they carried out, searched for an answer to the questions "Should be hospital efficiency or quality preferred?" or "Is it possible to apply together with it?". The study was carried out by means of DEA and continued two years in 187 hospitals in USA. According to the results obtained from the study, IT investments relatively affect the efficiency, quality and operational efficiency of the hospitals.

Chowdhury and Zelenyuk (2016), in the study they carried out in Ontario, Canada, between the years of 2003-2006, related to the performance of hospital services, tried to identify key factors determining the efficiency of hospital, making performance, effectiveness, and efficiency analyses As a result of the study, it was identified that some of organizational factors determining hospital efficiency were hospital occupancy rate, amount of work personnel individually produces (production amount per capita), incoming and outgoing patient transformation rate (inpatient and outpatient), case mix index, and geographical locations, and educational status of patients.

In the direction of this wide literature review carried out, it was decided to be carried out a study covering all of public hospitals in Turkey and, for this aim, in 2015, the efficiency of using input of all public hospitals in Turkey (1533 hospitals) according to the provinces was measured, and the performances of hospitals were introduced. Another aim of the study carried out is also to develop suggestions toward more improving of health services, making efficiency comparisons between the hospitals.

In this study, by means of output-oriented approach of method of DEA, the indices of constant return to scale, variable return to scale, and scale efficiency were calculated. While the calculations are made, first of all, all hospitals were evaluated together, their efficiency values were measured, then, the deficiencies or surpluses of the hospitals detected that they were not efficient, were identified; and, finally, in order to improve the performance of the hospitals, detected that they were not efficient, it was identified what should be done. In this context, the year 2015 data belonging to 1533 hospitals were drawn from website of Ministry of Health and, making the necessary arrangements, the technical and scale efficiencies of the hospitals were calculated. Utilizing the findings, obtained from the study, for the hospital not working efficiently to work more effectively, the amounts of output and input that are necessary to be increased and decreased were identified.

\section{Study Method and the Data Used}

In the study, in order to measure the efficiencies of hospitals, DEA was used. Because, considering that the DEA considers all inputs and outputs in selecting the successful service unit, it makes it superior to other efficiency analyzes. Instead of the performance averages that make DEA different from other methods, the optimal performance description (Aslan and Mete, 2007), the effectiveness of each decision point, the effectiveness of the ineffective decision points can be increased and the information about the decision points that can be used as a reference (Akgobek et al., 2015). While DEA can calculate the potential improvement values for the input variables in order for the inactive segments to be effective; Decision making methods such as Promethee and Electre, rank the total and technical efficiency, measure an effective decision making unit from the activity limit and measure the distance from the activity limit of this unit (Aladag et al., 2018).

The most important reason for selecting this method is that it can be easily used for more than one input and output. DEA uses all data, does not 
leave any data outside, and can be used without problem. In the study carried out, since the data of currency capital belonging to the hospitals and the data related to allowances reserved from the budget and expenditures cannot be supplied, they were not used. The data belonging to the variables of input and output, which are used in the study and affect hospital performance, were drawn from the year 2015 statistics lately published in 2016.

Indeed, there are a number of input and output variables in hospital businesses. However, the most important ones of the output variables are the numbers of medical examinations conducted in the hospital. In the same way, as input variable, the number of bed and the number of human resources are mostly dealt with. In the distribution of resources to the hospitals, first of all, since the number of bed is based on, considering that the number of bed will account for a number of input variables, it was handled as input variable. The data used in the study are the data published in the website of TR Ministry of Health and arranged according to international standards, these data were divided into two groups as input and output, utilizing the relevant literature. 6 input variables and 5 output variables, used in the study, were shown as follows (Table 1).

As seen in Table 1, in the study, as input variables, a total number of bed, the number of hospital, the number of attending physician, the number of general practitioner, the number of nurses, and the number other health personnel were taken. As output variables, a total number of patient treated, the number of surgical operation, the data of the number of inpatients, bed turnover, and crude mortality rate were taken.

In case that a number of input and output variables are included in the application, since the ability of DEA to decompose falls, this number should be kept as limited as possible. Since a total number of input and output have to be less than the number of decision unit (Aslan and Mete, 2007), in this study carried out, a total number of input and output variables were kept less than the number of decision unit. The data used in the analyses were handled in the daily basis and, determining the best production limits of hospitals, performance indicators, were assessed according to this limit. DEA and efficiency calculations were carried out by using WinDEAP 2.1 package program.

\subsection{The Findings Obtained from the Study}

Technical efficiency scores, calculated as a result of $D E A$, vary between 0 and 1 . That these values approach to 1 shows that efficiency increases and approaches to 0 shows that efficiency decreases. If technical efficiency score is 1, there is a case of full efficiency. Indeed, the case of full efficiency shows that the relevant hospital is in the boundary of the best production. For this aim, since efficiency score was compared to the value 1 , generally ineffectiveness score was also less than 1 . The case that the value of technical efficiency index is smaller than 1 means that business cannot produce maximum output with its existing inputs. In short, this case expresses that the actual output of business can be proportionally produced with less input. The hospitals, whose technical efficiency value is less than 1 (inefficient), are shown as follows (Table 2).

\subsubsection{Efficiency Scores of Public Hospitals in Turkey}

In Turkey, the scores of technical efficiency, pure efficiency and scale efficiency belonging to all public hospitals (1533 hospitals in 81 provinces) that are present in 2015 are shown as follows (Table 2).

Table 1: Variables Used in Work

\begin{tabular}{ll}
\hline Input Variables & Output Variables \\
\hline Total Number of Beds & Total number of patients treated \\
Number of hospitals & Number of Surgical \\
Number of Expert Doctors & The number of inpatients \\
Number of Practitioner Doctor & Bed Turnover Rate \\
Number of Nurses & Rough Death Rate \\
Number of Other Health Personnel & \\
\hline
\end{tabular}


Table 2: Efficiency Scores of Public Hospitals in Turkey

\begin{tabular}{|c|c|c|c|c|c|}
\hline SN & Provinces & CRS & VRS & Scale & \\
\hline 1 & Adana & 1.000 & 1.000 & 1.000 & - \\
\hline 2 & Adıyaman & 0.925 & 0.926 & 1.000 & - \\
\hline 3 & Afyonkarahisar & 0.919 & 0.924 & 0.995 & $\mathrm{drs}^{* *}$ \\
\hline 4 & Ağrı & 0.777 & 0.792 & 0.981 & irs* \\
\hline 5 & Amasya & 0.994 & 1.000 & 0.994 & $d r s^{* *}$ \\
\hline 6 & Ankara & 1.000 & 1.000 & 1.000 & - \\
\hline 7 & Antalya & 0.905 & 0.926 & 0.977 & $d r s^{* *}$ \\
\hline 8 & Artvin & 1.000 & 1.000 & 1.000 & - \\
\hline 9 & Aydın & 0.911 & 0.911 & 1.000 & - \\
\hline 10 & Balıkesir & 0.982 & 1.000 & 0.982 & $d r s^{* *}$ \\
\hline 11 & Bilecik & 1.000 & 1.000 & 1.000 & - \\
\hline 12 & Bingöl & 0.934 & 0.947 & 0.986 & irs* \\
\hline 13 & Bitlis & 0.959 & 0.967 & 0.991 & irs* \\
\hline 14 & Bolu & 1.000 & 1.000 & 1.000 & - \\
\hline 15 & Burdur & 0.955 & 0.964 & 0.991 & $\operatorname{irs}^{*}$ \\
\hline 16 & Bursa & 1.000 & 1.000 & 1.000 & - \\
\hline 17 & Çanakkale & 0.909 & 0.915 & 0.993 & $\operatorname{irs}^{*}$ \\
\hline 18 & Çankırı & 1.000 & 1.000 & 1.000 & - \\
\hline 19 & Çorum & 0.848 & 0.864 & 0.982 & $d r s^{* *}$ \\
\hline 20 & Denizli & 1.000 & 1.000 & 1.000 & - \\
\hline 21 & Diyarbakır & 0.811 & 0.817 & 0.993 & $\operatorname{irs}^{*}$ \\
\hline 22 & Edirne & 1.000 & 1.000 & 1.000 & - \\
\hline 23 & Elazığ & 0.920 & 0.923 & 0.998 & $\operatorname{irs}^{*}$ \\
\hline 24 & Erzincan & 0.821 & 0.845 & 0.972 & irs* \\
\hline 25 & Erzurum & 0.928 & 0.943 & 0.984 & irs* \\
\hline 26 & Eskişehir & 0.942 & 0.942 & 1.000 & - \\
\hline 27 & Gaziantep & 1.000 & 1.000 & 1.000 & - \\
\hline 28 & Giresun & 0.891 & 0.892 & 0.999 & $\mathrm{drs}^{* *}$ \\
\hline 29 & Gümüşhane & 0.891 & 0.909 & 0.980 & irs* \\
\hline 30 & Hakkari & 0.891 & 0.934 & 0.954 & irs* \\
\hline 31 & Hatay & 0.946 & 0.953 & 0.993 & $\mathrm{drs}^{* *}$ \\
\hline 32 & Isparta & 1.000 & 1.000 & 1.000 & - \\
\hline 33 & Mersin & 1.000 & 1.000 & 1.000 & - \\
\hline 34 & İstanbul & 1.000 & 1.000 & 1.000 & - \\
\hline 35 & İzmir & 0.906 & 0.954 & 0.949 & $\mathrm{drs}^{* *}$ \\
\hline 36 & Kars & 0.733 & 0.796 & 0.921 & $\operatorname{irs}^{*}$ \\
\hline 37 & Kastamonu & 0.937 & 0.970 & 0.966 & $\mathrm{drs}^{* *}$ \\
\hline 38 & Kayseri & 1.000 & 1.000 & 1.000 & - \\
\hline 39 & Kırklareli & 0.965 & 0.965 & 1.000 & - \\
\hline 40 & Kırşehir & 0.857 & 0.870 & 0.986 & irs* \\
\hline 41 & Kocaeli & 1.000 & 1.000 & 1.000 & - \\
\hline 42 & Konya & 0.855 & 0.874 & 0.977 & $d r s^{* *}$ \\
\hline
\end{tabular}


Table 2: Efficiency Scores of Public Hospitals in Turkey (Continuation of Table 2)

\begin{tabular}{|c|c|c|c|c|c|}
\hline SN & Provinces & CRS & VRS & Scale & \\
\hline 43 & Kütahya & 0.898 & 0.913 & 0.983 & $\mathrm{drs}^{* *}$ \\
\hline 44 & Malatya & 1.000 & 1.000 & 1.000 & - \\
\hline 45 & Manisa & 0.935 & 0.936 & 0.999 & $d r s^{* *}$ \\
\hline 46 & Kahramanmaraş & 0.956 & 1.000 & 0.956 & $\mathrm{drs}^{* *}$ \\
\hline 47 & Mardin & 1.000 & 1.000 & 1.000 & - \\
\hline 48 & Muğla & 0.808 & 0.814 & 0.992 & $d r s^{* *}$ \\
\hline 49 & Muş & 1.000 & 1.000 & 1.000 & - \\
\hline 50 & Nevşehir & 1.000 & 1.000 & 1.000 & - \\
\hline 51 & Niğde & 0.980 & 0.980 & 1.000 & - \\
\hline 52 & Ordu & 0.872 & 0.878 & 0.993 & $\mathrm{drs}^{* *}$ \\
\hline 53 & Rize & 1.000 & 1.000 & 1.000 & - \\
\hline 54 & Sakarya & 0.979 & 1.000 & 0.979 & $\mathrm{drs}^{* *}$ \\
\hline 55 & Samsun & 0.896 & 1.000 & 0.896 & $\mathrm{drs}^{* *}$ \\
\hline 56 & Siirt & 1.000 & 1.000 & 1.000 & - \\
\hline 57 & Sinop & 0.968 & 0.977 & 0.990 & irs* \\
\hline 58 & Sivas & 0.759 & 0.759 & 1.000 & - \\
\hline 59 & Tekirdağ & 1.000 & 1.000 & 1.000 & - \\
\hline 60 & Tokat & 0.847 & 0.855 & 0.991 & $\mathrm{drs}^{* *}$ \\
\hline 61 & Trabzon & 0.908 & 0.909 & 0.999 & $\mathrm{drs}^{* *}$ \\
\hline 62 & Tunceli & 1.000 & 1.000 & 1.000 & - \\
\hline 63 & Şanlıurfa & 1.000 & 1.000 & 1.000 & - \\
\hline 64 & Uşak & 1.000 & 1.000 & 1.000 & - \\
\hline 65 & Van & 1.000 & 1.000 & 1.000 & - \\
\hline 66 & Yozgat & 0.755 & 0.762 & 0.991 & irs* $^{*}$ \\
\hline 67 & Zonguldak & 0.909 & 0.914 & 0.995 & irs* \\
\hline 68 & Aksaray & 1.000 & 1.000 & 1.000 & - \\
\hline 69 & Bayburt & 1.000 & 1.000 & 1.000 & - \\
\hline 70 & Karaman & 0.834 & 0.852 & 0.979 & irs* $^{*}$ \\
\hline 71 & Kırıkkale & 0.965 & 0.987 & 0.978 & irs* \\
\hline 72 & Batman & 1.000 & 1.000 & 1.000 & - \\
\hline 73 & Şırnak & 0.903 & 0.916 & 0.986 & irs* \\
\hline 74 & Bartın & 1.000 & 1.000 & 1.000 & - \\
\hline 75 & Ardahan & 1.000 & 1.000 & 1.000 & - \\
\hline 76 & lğdır & 1.000 & 1.000 & 1.000 & - \\
\hline 77 & Yalova & 1.000 & 1.000 & 1.000 & - \\
\hline 78 & Karabük & 1.000 & 1.000 & 1.000 & - \\
\hline 79 & Kilis & 1.000 & 1.000 & 1.000 & - \\
\hline 80 & Osmaniye & 1.000 & 1.000 & 1.000 & - \\
\hline \multirow[t]{2}{*}{81} & Düzce & 0.996 & 1.000 & 0.996 & $d r s^{* *}$ \\
\hline & Average & 0.944 & 0.953 & 0.991 & \\
\hline
\end{tabular}

*increasing return to scale

** decreasing return to scale 
As seen in Table 2, according to the result of the analysis carried out, in the context of efficiency calculations of a total of 1533 present in 81 provinces, according to CRS (Constant Return to Scale) technical efficiency score, it was identified that although 775 hospitals in 36 provinces (the provinces numbered 1 , $6,8,11,14,16,18,20,22,27,32,33,34,38,41,44,47$, $49,50,53,56,59,62,63,64,65,68,69,72,74,75,76$, $77,78,79$ and 80 ) were efficient, 758 hospitals in 45 provinces (the provinces $2,3,4,5,7,9,10,12,13,15$, $17,19,21,23,24,25,26,28,29,30,31,35,36,37,39$, $40,42,43,45,46,48,51,52,54,55,57,58,60,61,66$, $67,70,71,73$ and 81 ) were inefficient.

\subsubsection{Adjustments That Are Necessary to Be Done for Making Efficient the Inefficient Hospitals}

As a result of calculations made above, for making the hospitals, identified that they are inefficient, to make efficient, using the values in reference set, the amounts of input or output that hospitals have to increase or reduce are calculated by means of the software. According to the results of analysis, among 1533 hospitals, in which efficiency analysis is made, those detected that they do not work efficient, are 758 hospitals in 45 provinces. For making efficient these 758 hospitals, identified that they are inefficient, the adjustments that are necessary to be done in the input and output variables were calculated by WinDEAP and these amounts of adjustments obtained are shown as follows (Table 3).

As seen in Table 3, it was identified that 758 hospitals in 45 provinces do not efficiently work and the existing cases of these hospitals i.e. the current data belonging to the input and output variables in the situation, in which hospitals are not efficient, are shown.

The name of the numbers assigned to the columns in Table 3 and 4 are. 1) A total number of bed, 2) the number of hospital 3) the number of attending physicians, 4) the number of general practitioner 5) the number of nurses 6) The number of other health personnel 7) a total number of patients treated, 8) the number of surgical operation 9) the number of inpatients, 10) bed turnover 11) crude mortality rate.

Table 3: Current Status of Hospitals Specified as Not Efficiency

\begin{tabular}{ccccccccccccc}
\hline SN & Prv. & $\mathbf{1}$ & $\mathbf{2}$ & $\mathbf{3}$ & $\mathbf{4}$ & $\mathbf{5}$ & $\mathbf{6}$ & $\mathbf{7}$ & $\mathbf{8}$ & $\mathbf{9}$ & $\mathbf{1 0}$ & $\mathbf{1 1}$ \\
\hline 1 & 2 & 1139 & 12 & 383 & 306 & 1169 & 1081 & 4532015 & 20994 & 89207 & 78 & 8 \\
\hline 2 & 3 & 1945 & 22 & 520 & 392 & 1379 & 1508 & 6088719 & 41347 & 133357 & 69 & 15 \\
\hline 3 & 4 & 858 & 11 & 224 & 295 & 635 & 681 & 3364 & 11033 & 61223 & 71 & 5 \\
\hline 4 & 5 & 783 & 7 & 190 & 195 & 702 & 803 & 3082520 & 10885 & 35045 & 45 & 24 \\
\hline 5 & 7 & 5527 & 43 & 2650 & 1339 & 4268 & 4481 & 19763948 & 156268 & 426030 & 77 & 17 \\
\hline 6 & 9 & 2838 & 23 & 1032 & 660 & 2090 & 2001 & 9755546 & 54860 & 227201 & 80 & 18 \\
\hline 7 & 10 & 3018 & 29 & 870 & 668 & 2200 & 2201 & 11011262 & 62845 & 176308 & 58 & 26 \\
\hline 8 & 12 & 642 & 8 & 111 & 155 & 568 & 607 & 1560084 & 8181 & 40697 & 63 & 6 \\
\hline 9 & 13 & 759 & 9 & 161 & 210 & 526 & 552 & 2199422 & 11868 & 57595 & 76 & 5 \\
\hline 10 & 15 & 667 & 8 & 147 & 195 & 586 & 754 & 2308755 & 12055 & 44686 & 67 & 14 \\
\hline 11 & 17 & 1344 & 16 & 506 & 302 & 1151 & 1127 & 4871652 & 24355 & 74473 & 55 & 24 \\
\hline 12 & 19 & 1542 & 16 & 323 & 327 & 1044 & 1300 & 4127480 & 19536 & 98047 & 64 & 19 \\
\hline 13 & 21 & 4508 & 24 & 1322 & 844 & 3347 & 2500 & 10965929 & 94392 & 295034 & 65 & 10 \\
\hline 14 & 23 & 2900 & 11 & 620 & 330 & 1398 & 1320 & 4718052 & 37136 & 134836 & 46 & 16 \\
\hline 15 & 24 & 601 & 11 & 176 & 143 & 489 & 574 & 1757479 & 8794 & 39530 & 66 & 15 \\
\hline 16 & 25 & 3611 & 24 & 727 & 505 & 1880 & 1620 & 6210468 & 75590 & 158451 & 44 & 13 \\
\hline 17 & 26 & 3439 & 16 & 990 & 481 & 2339 & 2141 & 7518804 & 64481 & 197247 & 57 & 20 \\
\hline & & & & & & & & & & &
\end{tabular}


Table 3: Current Status of Hospitals Specified as Not Efficiency (Continuation of Table 3)

\begin{tabular}{|c|c|c|c|c|c|c|c|c|c|c|c|c|}
\hline SN & Prv. & 1 & 2 & 3 & 4 & 5 & 6 & 7 & 8 & 9 & 10 & 11 \\
\hline 18 & 28 & 1428 & 18 & 284 & 280 & 1030 & 1239 & 3872532 & 19314 & 81203 & 57 & 18 \\
\hline 19 & 29 & 336 & 6 & 73 & 98 & 297 & 409 & 1019878 & 3144 & 20580 & 61 & 12 \\
\hline 20 & 30 & 485 & 5 & 92 & 114 & 332 & 351 & 1270768 & 6421 & 29014 & 60 & 5 \\
\hline 21 & 31 & 3133 & 24 & 1050 & 901 & 2441 & 2614 & 12729712 & 90755 & 278453 & 89 & 18 \\
\hline 22 & 35 & 11466 & 57 & 5872 & 2294 & 9017 & 7717 & 37532589 & 281036 & 677295 & 59 & 24 \\
\hline 23 & 36 & 762 & 9 & 214 & 184 & 460 & 494 & 1837817 & 13627 & 37977 & 50 & 11 \\
\hline 24 & 37 & 993 & 17 & 174 & 251 & 733 & 970 & 2822454 & 11111 & 48231 & 49 & 22 \\
\hline 25 & 39 & 867 & 9 & 244 & 197 & 640 & 723 & 3166768 & 14009 & 59786 & 69 & 13 \\
\hline 26 & 40 & 491 & 6 & 172 & 146 & 482 & 710 & 1833876 & 8443 & 36788 & 75 & 14 \\
\hline 27 & 42 & 6420 & 42 & 1931 & 1203 & 4455 & 4428 & 17869078 & 145510 & 393809 & 61 & 15 \\
\hline 28 & 43 & 1617 & 12 & 404 & 301 & 1207 & 1216 & 4730066 & 23285 & 81661 & 50 & 22 \\
\hline 29 & 45 & 4092 & 28 & 1250 & 780 & 2734 & 2515 & 12815529 & 78293 & 229104 & 56 & 20 \\
\hline 30 & 46 & 2710 & 20 & 662 & 555 & 2057 & 2033 & 8769347 & 58472 & 185540 & 68 & 14 \\
\hline 31 & 48 & 2060 & 24 & 818 & 642 & 1660 & 1907 & 8064312 & 41567 & 136891 & 66 & 15 \\
\hline 32 & 51 & 785 & 8 & 178 & 190 & 580 & 724 & 2832176 & 11826 & 50397 & 64 & 12 \\
\hline 33 & 52 & 1818 & 17 & 518 & 435 & 1473 & 1601 & 6099441 & 39728 & 125800 & 69 & 16 \\
\hline 34 & 54 & 1741 & 18 & 690 & 546 & 1425 & 1563 & 8242764 & 50106 & 133008 & 76 & 16 \\
\hline 35 & 55 & 4364 & 28 & 1435 & 734 & 3073 & 3123 & 11726395 & 97200 & 271411 & 62 & 27 \\
\hline 36 & 57 & 479 & 7 & 120 & 135 & 465 & 576 & 1845739 & 8680 & 29395 & 61 & 16 \\
\hline 37 & 58 & 2559 & 19 & 552 & 391 & 1320 & 1481 & 5185792 & 36400 & 109167 & 43 & 18 \\
\hline 38 & 60 & 1800 & 15 & 437 & 358 & 1232 & 1597 & 5060988 & 32676 & 111911 & 62 & 15 \\
\hline 39 & 61 & 3221 & 22 & 875 & 496 & 2521 & 2554 & 7810510 & 59980 & 200183 & 62 & 17 \\
\hline 40 & 66 & 894 & 16 & 250 & 304 & 866 & 1075 & 3118985 & 15932 & 55490 & 62 & 12 \\
\hline 41 & 67 & 2123 & 12 & 566 & 365 & 1445 & 1138 & 5581789 & 38458 & 124185 & 58 & 20 \\
\hline 42 & 70 & 527 & 5 & 155 & 158 & 509 & 541 & 1921761 & 9917 & 33554 & 64 & 12 \\
\hline 43 & 71 & 1116 & 7 & 307 & 157 & 739 & 1068 & 2330255 & 18025 & 51931 & 46 & 22 \\
\hline 44 & 73 & 722 & 9 & 162 & 196 & 527 & 559 & 2365367 & 12099 & 44536 & 62 & 14 \\
\hline 45 & 81 & 703 & 8 & 312 & 185 & 626 & 587 & 2982168 & 15431 & 51389 & 73 & 20 \\
\hline
\end{tabular}

Table 4: Corrections to be made in not efficiency hospitals

\begin{tabular}{llllllllllll}
\hline Prv. & $\mathbf{1}$ & $\mathbf{2}$ & $\mathbf{3}$ & $\mathbf{4}$ & $\mathbf{5}$ & $\mathbf{6}$ & $\mathbf{7}$ & $\mathbf{8}$ & $\mathbf{9}$ & $\mathbf{1 0}$ & $\mathbf{1 1}$ \\
\hline 2 & -85 & -1 & -29 & -23 & -282 & -81 & 0 & 7519 & 0 & 6 & 5 \\
\hline 3 & -148 & -11 & -40 & -30 & -237 & -254 & 0 & 3338 & 0 & 0,4 & 3 \\
\hline 4 & -179 & -6 & -47 & -64 & -149 & -142 & 2773289 & 3175 & 0 & 14 & 2 \\
\hline 5 & 0 & 0 & 0 & 0 & 0 & 0 & 0 & 0 & 0 & 0 & 0 \\
\hline 7 & -410 & -15 & -800 & -99 & -554 & -1405 & 0 & 1254 & 0 & 12 & 0 \\
\hline 9 & -252 & -5 & -183 & -59 & -196 & -177 & 0 & 27596 & 0 & 7 & 3 \\
\hline 10 & 0 & 0 & 0 & 0 & 0 & 0 & 0 & 0 & 0 & 0 & 0 \\
\hline 12 & -190 & -5 & -6 & -26 & -219 & -142 & 0 & 622 & 0 & 23 & 3 \\
\hline 13 & -77 & -2 & -5 & -12 & -53 & -18 & 0 & 278 & 0 & 7 & 1 \\
\hline 15 & -151 & $-0,3$ & -5 & -7 & -121 & -145 & 0 & 0 & 0 & 9 & 1 \\
\hline 17 & -114 & -6 & -43 & -26 & -183 & -171 & 0 & 6958 & 4645 & 13 & 7 \\
\hline 19 & -524 & -8 & -44 & -45 & -308 & -334 & 0 & 6117 & 0 & 27 & 0 \\
\hline 21 & -1206 & -4 & -288 & -154 & -978 & -457 & 0 & 14010 & 0 & 24 & 4 \\
\hline 23 & -1246 & -1 & -123 & -26 & -161 & -126 & 0 & 3015 & 0 & 31 & 0 \\
\hline 24 & -93 & -7 & -27 & -22 & -100 & -104 & 0 & 2518 & 0 & 13 & 0 \\
\hline 25 & -1328 & -9 & -42 & -29 & -270 & -229 & 1232143 & 0 & 38343 & 39 \\
\hline
\end{tabular}




\begin{tabular}{|c|c|c|c|c|c|c|c|c|c|c|c|}
\hline 26 & -833 & -1 & -151 & -28 & -456 & -285 & 0 & 71 & 0 & 15 & 0 \\
\hline 28 & -381 & -11 & -31 & -30 & -354 & -407 & 0 & 2776 & 0 & 17 & 1 \\
\hline 29 & -57 & -3 & -7 & -9 & -43 & -71 & 0 & 1222 & 0 & 16 & 1 \\
\hline 30 & -154 & -3 & -6 & -8 & -72 & -23 & 0 & 157 & 0 & 24 & 5 \\
\hline 31 & -147 & -4 & -98 & -42 & -298 & -679 & 0 & 4715 & 0 & 3 & 0 \\
\hline 35 & -528 & -3 & -819 & -287 & -829 & -1269 & 0 & 4220 & 23128 & 10 & 0 \\
\hline 36 & -291 & -7 & -74 & -38 & -106 & -101 & 0 & 0 & 0 & 24 & 6 \\
\hline 37 & -384 & -12 & -5 & -57 & -243 & -427 & 0 & 421 & 0 & 21 & 0 \\
\hline 39 & -31 & -3 & -9 & -7 & -24 & -25 & 0 & 2892 & 0 & 0 & 8 \\
\hline 40 & -64 & -2 & -22 & -19 & -118 & -237 & 0 & 2260 & 0 & 6 & 7 \\
\hline 42 & -1536 & -19 & -243 & -151 & -832 & -1245 & 0 & 3577 & 0 & 20 & 2 \\
\hline 43 & -241 & -1 & -35 & -26 & -314 & -170 & 0 & 5721 & 7371 & 15 & 0 \\
\hline 45 & -850 & -5 & -80 & -50 & -346 & -161 & 0 & 3020 & 0 & 16 & 0 \\
\hline 46 & 0 & 0 & 0 & 0 & 0 & 0 & 0 & 0 & 0 & 0 & 0 \\
\hline 48 & -382 & -11 & -214 & -120 & -373 & -566 & 0 & 1939 & 0 & 12 & 10 \\
\hline 51 & -124 & -4 & -4 & -4 & -84 & -165 & 0 & 458 & 0 & 6 & 11 \\
\hline 52 & -222 & -5 & -63 & -53 & -380 & -381 & 0 & 0 & 0 & 8 & 0 \\
\hline 54 & 0 & 0 & 0 & 0 & 0 & 0 & 0 & 0 & 0 & 0 & 0 \\
\hline 55 & 0 & 0 & 0 & 0 & 0 & 0 & 0 & 0 & 0 & 0 & 0 \\
\hline 57 & -11 & -1 & -3 & -3 & -61 & -50 & 0 & 0 & 2227 & 6 & 3 \\
\hline 58 & -944 & -8 & -133 & -94 & -321 & -357 & 0 & 0 & 0 & 23 & 1 \\
\hline 60 & -261 & -5 & -64 & -52 & -304 & -537 & 0 & 3454 & 0 & 6 & 3 \\
\hline 61 & -709 & -4 & -80 & -45 & -766 & -716 & 0 & 4957 & 0 & 14 & 0 \\
\hline 66 & -212 & -8 & -59 & -72 & -302 & -373 & 0 & 0 & 0 & 10 & 5 \\
\hline 67 & -578 & -2 & -53 & -32 & -304 & -98 & 0 & 4123 & 0 & 14 & 2 \\
\hline 70 & -78 & -2 & -23 & -24 & -140 & -80 & 0 & 0 & 0 & 9 & 7 \\
\hline 71 & -374 & 0 & -68 & -2 & -158 & -447 & 31483 & 0 & 0 & 28 & 0 \\
\hline 73 & -148 & -4 & -14 & -17 & -105 & -47 & 0 & 0 & 299 & 13 & 0 \\
\hline 81 & 0 & 0 & 0 & 0 & 0 & 0 & 0 & 0 & 0 & 0 & 0 \\
\hline Total & -15458 & -207 & -4011 & -1869 & -10862 & -12621 & 4036915 & 114864 & 76013 & 12,34 & 2,13 \\
\hline
\end{tabular}

In the following Table, among 1533 hospitals, for 758 hospitals, identified that they do not efficiently work, to work efficiently, the amounts of adjustments (increasing/reducing) that has to be done are put in order according to the provinces (Table 4).

As seen in Table 4, in the hospitals of 45 provinces, identified that they do not efficiently work, the amounts that have to be increased (positive values)/ reduced (negative values) were calculated by taking the difference of the existing values and targeted values.

As seen in Table 4, among the existing 1533 hospitals in 81 provinces across Turkey, for being able to make efficient 758 hospitals, identified that they do not efficiently work, across the country, it is necessary to reduce a total number of bed by 15458 , reduce the number of hospital by 207, reduce the number of attending physician by 4011 , reduce the number of general practitioner by 1869 , reduce the number of nurses by 10,862 , reduce the number of other health personnel by 12621 , increase a total number of treated patients by $4,036,915$, increase the number of surgical operation by 114,864 , increase the number of inpatients by 76013 , raise bed turnover to a rate of 12.34 , and bring crude mortality rate into a rate of 2.13 .

\subsubsection{The effect of input/output variables on efficiency values}

In this part of the study, the efficiency values of 6 input variables used in efficiency study and 5 output variables and correlation between them will be examined. 
Table 5: Correlation between Input / Output Variables and Efficiency Values

\begin{tabular}{lllrrrrr}
\hline Variables & \multicolumn{1}{c}{$\mathrm{X}$} & $\mathrm{S}$ & $\begin{array}{c}\text { Technic } \\
\text { efficien. }\end{array}$ & $\begin{array}{c}\text { Number } \\
\text { pat.tr. }\end{array}$ & $\begin{array}{c}\text { Number } \\
\text { of surg. }\end{array}$ & $\begin{array}{c}\text { Bed. tur. } \\
\text { rate }\end{array}$ & $\begin{array}{c}\text { Rough } \\
\text { dea rate }\end{array}$ \\
\hline Technical efficiency & 0,94420 & 0,070130 & 1 & & & & \\
\hline Number of patient treated & 8107877 & 1,414 & 0,115 & 1 & & \\
\hline Number of surgical & 58891 & 111995 & 0,116 & $0,993^{* *}$ & 1 & 1 \\
\hline Bed turnover rate & 65,94 & 13,93 & $0,232^{*}$ & 0,012 & 0,004 & 1 \\
\hline Rough death rate & 16,12 & 5,72 & 0,168 & 0,198 & 0,183 & $-0,313^{* *}$ & 1 \\
\hline
\end{tabular}

*. Correlation is significant at the 0.05 level (2-tailed).

**. Correlation is significant at the 0.01 level (2-tailed).

As a result of correlation analysis carried out between the technical efficiency values and input and output variables, it was identified that: 1) there was a correlation between technical efficiency and a total number of bed in the rate of $0.082,2$ ) the number of bed, in the rate of $0.050,3$ ) the number of attending physician, in the number of $0.099,4$ ) general practitioner, in the rate of $0.074,5$ ) the number of nurses, in the number of 0.083 . 6) the other health personnel, in the rate of 0.073 ; 7) a total number of treated patient, in the rate of $0.115,8)$, the number of surgical operation, in the rate of $0.116,9)$ the number of inpatients, in the rate of $0.117,10$ ) bed turnover, in the rate of 0.232 and 11) crude mortality, 0.168 .

As seen in Table 5, it is seen that the correlation value between technical efficiency level and bed turnover is positive and significant at the level of $p$ $<0.05(r=0.232)$. According to these results, bed turnover, among 11 input and output variables, affect the technical efficiency level the most (23\%). That is, as bed turnover increases, the efficiency of hospital also increases, depending on this. According to these results, for increasing the efficiency of hospitals, first of all, it is necessary to increase bed turnover and, after that, crude mortality rate, the number of surgical operation, and a total number of patient treated, in order.

\section{CONCLUSION AND SUGGESTIONS}

Managing the institutes presenting health services having critical importance in terms of human quality of life and labor effectiveness with understanding of efficiency and effectiveness is considerably important to the businesses of today surviving in the advanced competitive environments. That hospitals presenting health services to society can effectively and efficiently sustain their activities depends on their doing cost optimization and increasing their competitive powers. Especially, the rapid increase of the number of health organizations that alternatively develop to public hospitals in Turkey has also increased the importance given to this issue much more and improved service quality and competition in favor of customer.

Nowadays, together with the material and economic possibilities of people, service expectations of customers have also increased and, depending on this, the sectorial value of this service reached important dimensions. When the experience that $\mathrm{EU}$ countries take health services to forefront but excessively increase costs, excessively spending, is considered, effectively giving this service, increasing service efficiency, and providing cost minimization by reducing excessive expenditures have become an important focus point for today service presenters.

In this context, examining many relevant applications made at international level, a large literature review was conducted, and an application study covering all Turkey was carried out. The aim of this application study carried out is to obtain the data that will enable a total of 1533 public hospitals that are existent in 81 provinces of Turkey to operate in high performance and effectively. Therefore, first of all, the current situations, deficiencies, surpluses, and problems of the hospitals and, later, those being to be done were determined for the problems identified to be solved and hospitals to work more effectively.

According to the study results, the technical efficiency of 1533 hospitals being active in 81 provinces and presenting similar health services was measured by means of DEA and that 775 present in 36 provinces work efficiently and 758 present in 45 provinces do not work efficiently. Since the businesses that are efficient from technical point view present service in lower cost compared to ineffective businesses, this case provides an important cost advantage to the businesses. When evaluated in terms of cost advantage, that the costs of hospitals not being able to produce service technically are higher will prevent them from being active in se- 
ctor for longer time in the same way. For this reason, it is necessary for ineffective hospitals to absolutely increase service outputs they present with a certain amount of input in the proceeding periods. Increasing the number of hospitals that are technically efficient in health sector means that the similar services in market can be presented more cheaply, and this case will increase competition in health sector. In the following years, just as the fact that similar studies proliferate and become widespread can increase the efficiencies of hospitals in respect of year, it can produce more benefit to all parts utilizing this service.

In the study, for inefficient hospitals to be able to make efficient, the amounts of input and output that hospitals have to increase or decrease by using the values in reference sets, were calculated by means of DEA package program. Of 1533 hospitals in 81 provinces analyzed across Turkey, for 758 hospitals, identified that they are not efficient, to be able to become efficient, it is necessary to reduce a total number of bed by 15458 , reduce the number of hospital by 207 , reduce the number of attending physician by 4011 , reduce the number of general practitioner by 1869 , reduce the number of nurses by 10,862 , reduce the number of other health personnel by 12621 , increase a total number of treated patients by $4,036,915$, increase the number of surgical operation by 114,864 , increase the number of inpatients by 76013 , raise bed turnover to a rate of 12.34 , and bring crude mortality rate into a rate of 2.13 .

In this part of the study, as a result of correlation analysis between 6 input and 5 output variables, used in efficiency study, and efficiency values of hospitals, it was identified that there was the most relationship between technical efficiency level and bed turnover (at the significant level of $5 \%$ and in the rate of $23 \%$ ). According to this result, among 11 input and output variables, bed turnover affect technical efficiency level the most. Namely, as bed turnover increases, efficiency of hospital also increases. In a study, carried out in Taiwan in a quality supporting this finding, $\mathrm{Hu}$ and Huang
(2004) expressed that bed turnover significantly increased efficiency of hospitals.

Again, according to the findings obtained from the study, for increasing efficiency of hospitals, what is necessary to be done after increasing bed turnover is to increase the number of surgical operation and a total number of treated patients in order. A study in the direction supporting this finding was carried out in Ontario, Canada, between the years of 2003-2006 and Chowdhury and Zelenyuk (2016) put forward that a total number of outpatient and inpatient was determinant in increasing hospital efficiency.

In the scope of these results obtained, some identification that stands out to be able to suggest to the relevant researchers and practitioners. International information infrastructure should be developed, and its sharing should be increased. For increasing hospital efficiency, it is necessary the required legal and political arrangements without delaying to standardize, store, and share the data; to strengthen infrastructure (Oderkirk et al., 2013: 9); to reorganize and improve the management and resource distribution (Dimas et al., 2012); to standardize assessment criteria and data at international level (Davis et al., 2013); to increase technology investments (Gholami vd., 2015); and to increase bed turnover, the number of surgical operation made, and the number of patient treated.

That the hospitals in the rural and urban regions show similarity to each other in the dimension of effectiveness-performance and that the hospitals in rural sector better performance but relatively (Garcia-Lacalle and Martin, 2010) support the suggestion that several reforms should be done in service strategies of the businesses of interest and costs should be reduced.

This study was conducted to determine the performance level of health services in Turkey, it could be improved with more comprehensive studies to be conducted in the future. For example, the contribution of the study to the literature can be increased by making comparisons and evaluations with the performance levels of health services provided in EU countries. 


\section{REFERENCES}

Akal, Z. (2000). Performance Measurement and Control in Operations, Multipurpose Performance Indicators, MPM, No: 473, Ankara.

Akgobek, O., Nişanci, I., Kaya, S., Eren, T. (2015). Measuring the Performance of Branches of an Educational Institution Using the DEA Approach, Social Sciences Research Journal, Volume 4, Issue 3, 43-54 (September 2015).

Aladag, Z., Alkan, A., Güler, E., Özdin, Y. (2018). Performance Evaluation of Academic Units with Data Envelopment Analysis and Promethee Methods: The Case of Kocaeli University, Erciyes University Journal of Institute of Science and Technology, Volume 34, Issue 1, p.1-13, Kayseri.

Aslan, S. and Mete, M. (2007). Data Envelopment Analysis Method in Performance Measurement: Example of Birth and Children Hospitals Depended on Ministry of Health, Istanbul University, Faculty of Business Administration, Management Journal, Vol: 36, No: 1, p.44-63.

Ayrıcay, Y. and Ozcalıcı, M. (2014). Between the years of 1997-2012 in Turkey DEA Related Published Studies of Academic, Kahramanmaras Sütcüimam University, Faculty of Economics Journal, Volume 4, Number 1, p. 246-279.

Bayraktutan, Y. and Pehlivanoglu, F. (2012). Efficiency Analysis in Healthcare Establishments: Kocaeli Example, Journal of Kocaeli University Social Sciences Institute, Issue 23, p. 127-162

Bernd, H. and Irvine, L. (2001). On the Efficiency of Public, Welfare and Private Hospitals in Germany Over Time - A Sectoral DEA-Study. Health Services Management Research, Vol. 14, 2001, pp. 263-274. Available at: http://ssrn.com/abstract $=993391$

Bowlin, W. F. (1998). Measuring Performance: An Introduction to Data Envelopment Analysis (DEA), The Journal of Cost Analysis, 3-27.

Charnes, A., Cooper, W.W., Rhodes, E. (1978). Measuring the efficiency of decision making units, European Journal of Operation Research, 2, p.429-444.

Chowdhury, H. and Zelenyuk, V. (2016). Performance of hospital services in Ontario: DEA with truncated regression approach, Omega, Volume 63, September 2016, p.111-122.

Cooper, W.W., Seiford, L. M. and Zhu, J. (2004). Handbook on Data Envelopment Analysis, Kluwer Academic Publishers, Boston.
Caglar, A. (2003). Activity Measurement of Municipalities by Data Envelopment Analysis. Doctorate Thesis, Hacettepe University Institute of Science, Department of Statistics, Ankara.

Celik, T. and Esmeray, A. (2014). Measurement of Cost Effectiveness in Private Hospitals in Kayseri by Data Envelopment Method, International Alanya Business Administration Journal, Volume: 6, Issue : 2, p. 45-54.

Davis, P., Barry, M., Karl P., Phil H., Roy Lay-Yee, Jackie, C. and Patrick G. (2013). Efficiency, effectiveness, equity (E3). Evaluating hospital performance in three dimensions. Health Policy, 112(2013):19-27, https:// www.elsevier.com/locate/healthpol

Dimas, G., Goula, A. and Soulis, S. (2012). Productive performance and its components in Greek public hospitals. Operational Research, May 2012, DOI: 10.1007/s12351-010-0082-2, https://www.researchgate.net/publication/225985728

Ferrier, G.D. and Valdmanis, V.G. (2004). Do mergers improve hospital productivity? Journal of the Operational Research Society, Volume: 55, Issue: 10, pp.1071-1080

Garcia-Lacalle, J. and Martin, E. (2010). Rural vs Urban hospital performance in a 'competitive' public health service, Social Science \& Medicine, Doi: 10.1016/j.socscimed.2010.05.043

Gholami, R., Dolores A.H. and Ali, E. (2015). Hospital performance: efficiency or quality? Can we have both with it? Expert Systems with Applications, Volume: 42, Issue: 12 , p.5390-5400

Guzel, D., Celik, A.K. and Akbaba, A.I. (2012). Relevant Efficiency Analysis of University and State Hospitals in Erzurum with Data Envelopment Method, 12th Production Research Symposium-UAS 2012 Proceedings Book, p.975-981, İzmir.

Helmig, B. and Lapsley, I. (2001). On the Efficiency of Public, Welfare and Private Hospitals in Germany Over Time - A Sectorial DEA-Study, Health Services Management Research, Vol. 14, pp. 263-274. http:// ssrn.com/abstract $=993391$

Hofmarcher, M. M., Paterson, I. and Riedel, M. (2002). Measuring Hospital Efficiency in Austria-A DEA Approach. Health Care Management Science, 5, p.7-14. Kluwer Academic Publishers.

Hu, J. and Huang, Y. (2004). Technical Efficiencies in Large Hospitals: A Managerial Perspective, 
International Journal of Management, Vol. 21 No. 4, December 2004, p.506-513.

Karagoz S, and Balci, A. (2007). Effectiveness of health management departments of universities that train health managers in Turkey, International Journal of Health Planning and Management, 22(4): 263-288.

Karahan, M. and Akdag, R. (2014). Service Efficiency Measurement by Data Envelopment Analysis: Diyarbakir DISKI Example, Selçuk University Social Sciences Institute Magazine, Dr. Mehmet YILDIZ Special Issue.

Kirigia, J.M., Emrouznejad, A., Sambo, L.G., Munguti, N. and Liambila, W. (2004). Using Data Envelopment Analysis to Measure the Technical Efficiency of Public Health Centers in Kenya DEA Analytical Framework, Journal of Medical Systems, Vol. 28, No. 2, p.155-166.

Oderkirk, J., Ronchi, E. and Klazinga, N. (2013). International comparisons of health system performance among OECD countries: Opportunities and data privacy protection challenges, Health Policy, 112 (2013): 9-18.

Parkin, D. and Hollingsworth, B. (1997). Measuring production efficiency of acute hospitals in Scotland, 1991-94: Validity issues in data envelopment analysis. Appl. Econ. 29(11):1425-1433.

Tavares, G. (2002). A Bibliography of Data Envelopment Analysis (1978-2001), Rutcor Research Report, 01-02.
Tetik, S. (2003). Data Envelopment Analysis in Determining Operational Performance, Celal Bayar University Faculty of Economics and Administrative Sciences, Journal of Management and Economics, Vol: 10, No: 2, p.221-229, Manisa.

Thanassoulis, E., Boussfofiane, A., and Dyson, R.G. (1995). Exploring output quality targets in the provision of perinatal-care in England using data envelopment analysis. Eur. J. Oper. Res. 80:588-607.

Tunca, M.Z., Omurbek, N. and Bal, V. (2010). An Activity Measurement Study in Training and Research Hospitals with Data Envelopment Analysis, 10th National Production Research Symposium, 16-18 September 2010, Proceding Book, p.1-8.

Widiarto, I., Emrouznejad, A. and Anastasakis, L. (2017). Observing choice of loan methods in not-for-profit microfinance using data envelopment analysis, Expert Systems With Applications, 82 (2017): 278-290, journal homepage: www.elsevier.com/locate/eswa

Yu, J. and Zhang Y. (2017) Comparison of Single-Payer and Non Single-Payer Health Care Systems: A Study of Health Administration Efficiency. Modern Economy, 8, p.816-833. https://doi.org/10.4236/ me.2017.86057

Yun, Y. B., Nakayama H. and Tanino T. (2004). A Generalized Model for Data Envelopment Analysis, European Journal of Operational Research, 157, p.87-105. 